\title{
Rural Electrification using Iliceto Shield Wire Scheme in Developing Countries: Tanzania Case Study
}

\author{
Heavenlight M Munisi* and Santos Kihwele \\ Department of Electrical Engineering, University of Dar es Salaam, P.O. Box 35131, Dar es \\ Salaam, Tanzania. \\ E-mail addresses: heavenmunisi@yahoo.com,kihwele2002@yahoo.com \\ *Corresponding author
}

Received 15 Jul 2021, Revised 16 Oct 2021, Accepted 23 Oct 2021, Published Dec 2021

DOI: https://dx.doi.org/10.4314/tjs.v47i5.7

\begin{abstract}
Rural electrification rate in Tanzania is still very low despite the efforts made by the Rural Energy Agency (REA) in Tanzania. Rural electrification using medium voltage (MV) method has two major obstacles. First obstacle is high cost associated with the cost of extending the grid electricity to rural areas. Second obstacle is remoteness of the villages, which leads to high power loss during transmission. In lieu of economic extension of rural electrification areas, this paper proposes a low cost solution of Iliceto Shield Wire Scheme (ISWS). This technique involves insulating shield wires (SW) from high voltage $(132-400 \mathrm{kV})$ transmission line and energizing (11-33 kV) them from nearby substation at one line and use ground as MV phase conductor. The paper undertakes literature review of ISWS technology as installed in other developing countries. After that, a case study is selected in Mpaji village in Tanga region Tanzania. Analysis was made on voltage drop, power flow and cost for rural electrification using ISWS technology. Using ISWS for Mpaji village resulted in $10.89 \%$ voltage drop with total investment cost of about $49.4 \%$ compared to MV conventional method.
\end{abstract}

Keywords: Iliceto Shield Wire Scheme (ISWS), Medium Voltage, Rural Electrification.

\section{Introduction}

Majority of rural people in Tanzania have no access to modern energy services especially electricity. According to the International Energy Agency (IEA), "Tanzania Energy outlook 2019" statistics show that about $37 \%$ of the Tanzania population have access to grid electricity (IEA 2019). Enhancing energy supply in rural areas through private and public sectors participation will contribute significantly in development of the rural Tanzanians lives.

The Iliceto Shield Wire Scheme (ISWS) is a solution for rural electrification with the main purpose of minimizing the cost of power supply from the interconnected grid to villages, communities, farms, factories and water pumping stations located near or at some distance from the route of the highvoltage transmission lines according to Iliceto and Emeritus (2016). ISWS technique is being proposed in order to replace the MV conventional connection to the grid which is not economically feasible for the loads connected far from the MV lines and with small power demands (Iliceto et al. 2004, Iliceto et al. 2005, Chaves and Tavares 2018). ISWS is well implemented in several countries worldwide such as Brazil, Ethiopia, Ghana, Laos, Togo, Burkina Faso and Sierra Leone according to EU Energy Initiative (2015).

ISWS have been developed from combination of two technologies. First is the 
use of Insulated SWs in the long high voltage (HV) lines carrying bulky amount of power so as to reduce joule losses (Shu et al. 2020). The second is the single wire earth return technology (Iliceto et al. 2002, Porzi 2021). The ISWS is characterized by direct use of the SWs of the HV transmission line (TL) to transport MV power along the transmission line to a convenient location and then extend the spur line by means of normal MV pole lines to the rural areas (Iliceto et al. 2000, EU Energy Initiative 2015). Distribution transformer is installed near the load to supply electricity to the loads (Bakkabulindi 2012, Bellitto 2021). Transporting electricity using SWs it is necessary to insulate SWs from the towers of HV TL and energize them up to MV level according to Iliceto and Emeritus (2016). This MV level can vary from $11 \mathrm{kV}$ to the upper limit of $33 \mathrm{kV}$ which is the maximum standard voltage. In ISWS the SWLs have the same power distribution capabilities and voltage drops as MV conventional lines of the same rated voltage and length equipped with conductors of the same ohmic resistance as the SWs (Cinieri 1999, Gatta et al. 2005, Huertas and Tavares 2018).

\section{ISWS technology}

Different schemes of ISWS (Iliceto et al. 1989, Cinieri et al. 1992, Iliceto and Emeritus 2016) are presented in Figure 1: Scheme A"Single-phase earth return"; Scheme B"Single-phase metallic return"; Scheme C"Three-phase tertiary winding"; Scheme D"Three-phase with interposing transformer".

In this paper scheme $C$ will be used since the scheme does not need addition of transformer and will provide three-phase four wire electricity.
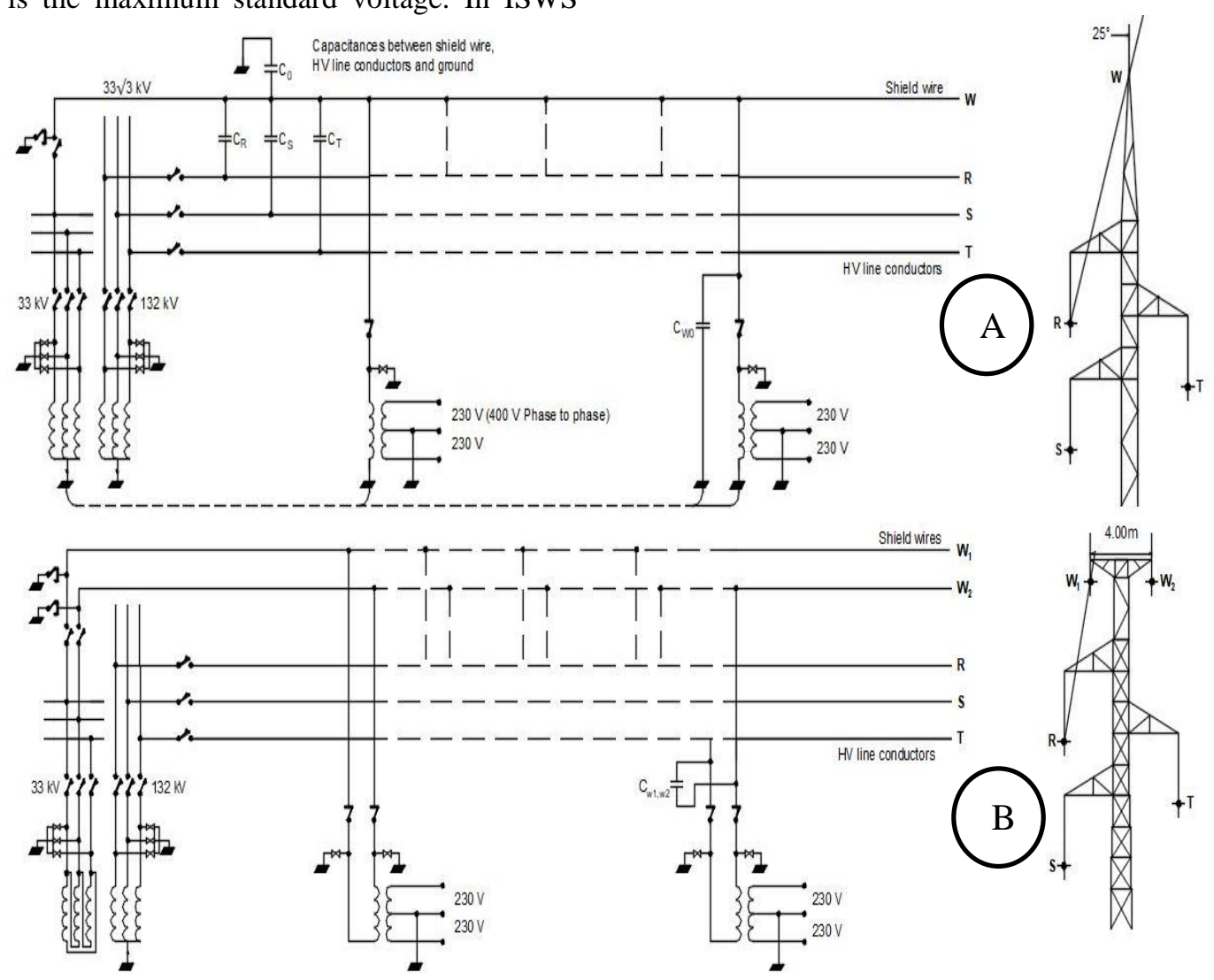

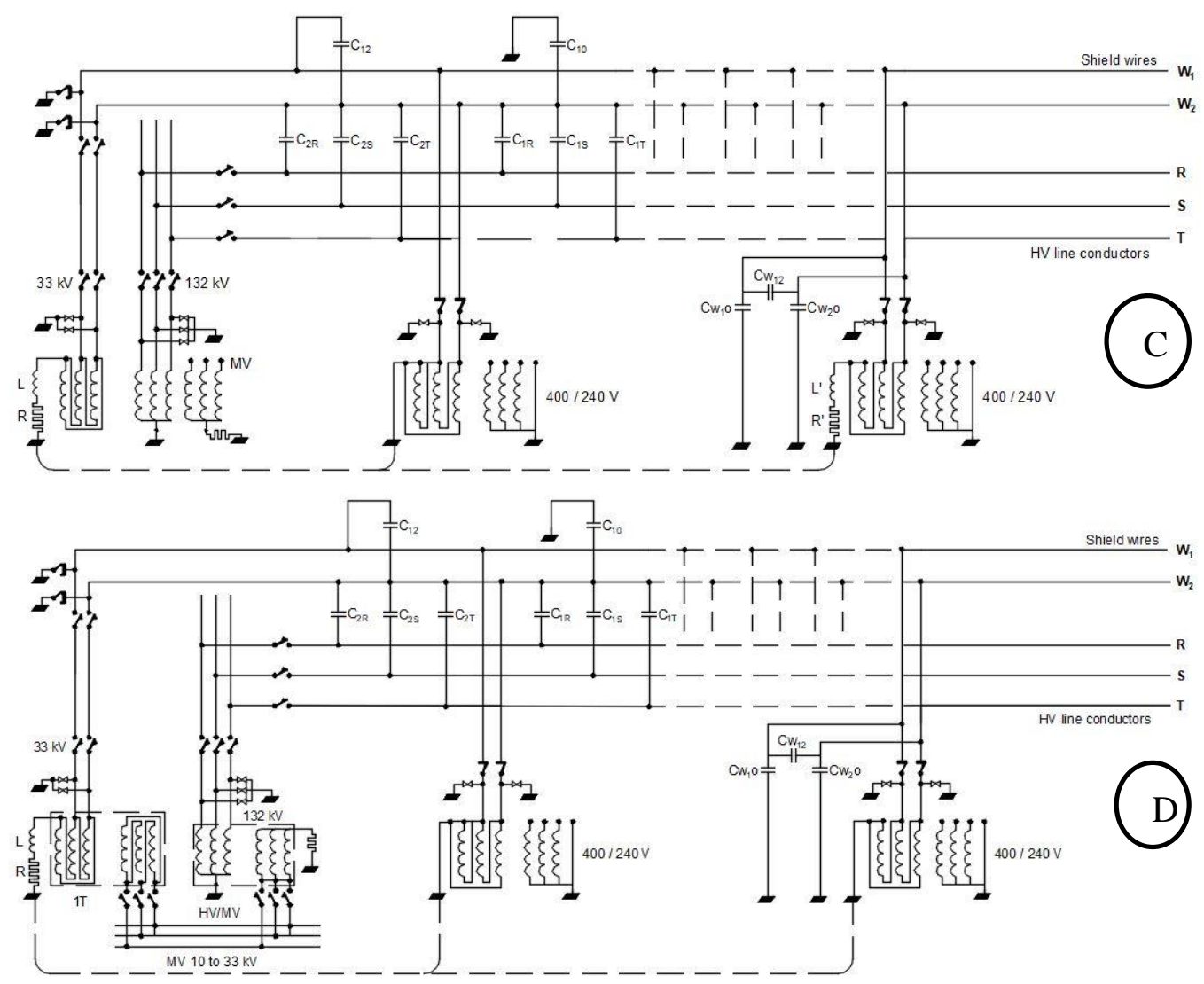

Figure 1: ISWS schemes.

\section{Materials and Methods \\ Case study description}

The Chalinze-Hale-Tanga HV TL was built for power supply to major areas and for connecting remote power plants to the grid as shown in Figure 2. Adjacent to the route and not so far from highways there are several villages, mines and small towns without electricity supply. Examples of these villages include Lunga, Lugoba, Mindutulieni, Mndukene, Mtindi, Mapinduzi, Mpaji, Mchokozi, Kitumbi, Komnara, Komkomba and Zunga villages. Figure 3 shows some of the villages located between Chalinze substation and Hale substation without electricity. 


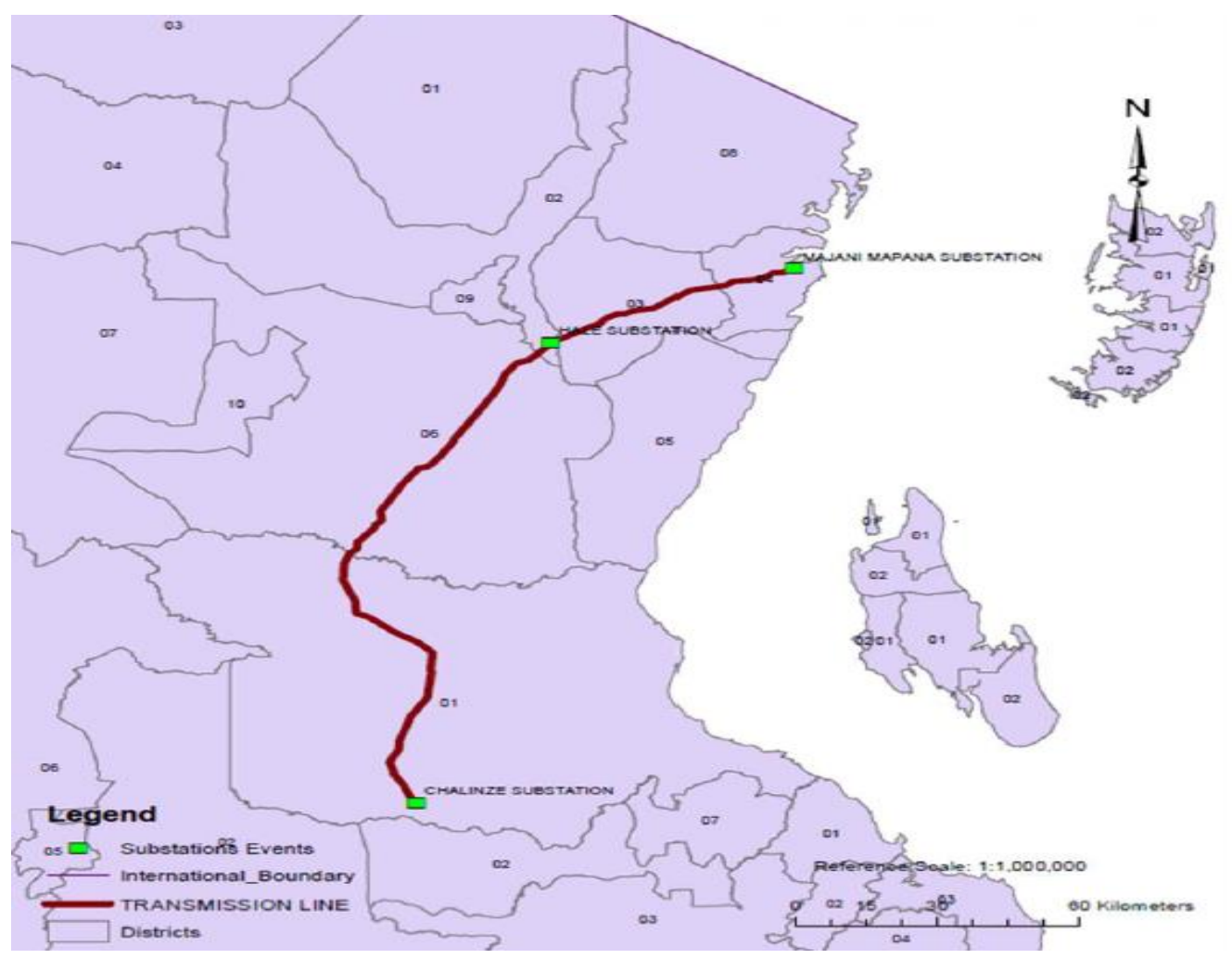

Figure 2: Chalinze-Hale-Tanga high voltage transmission line.

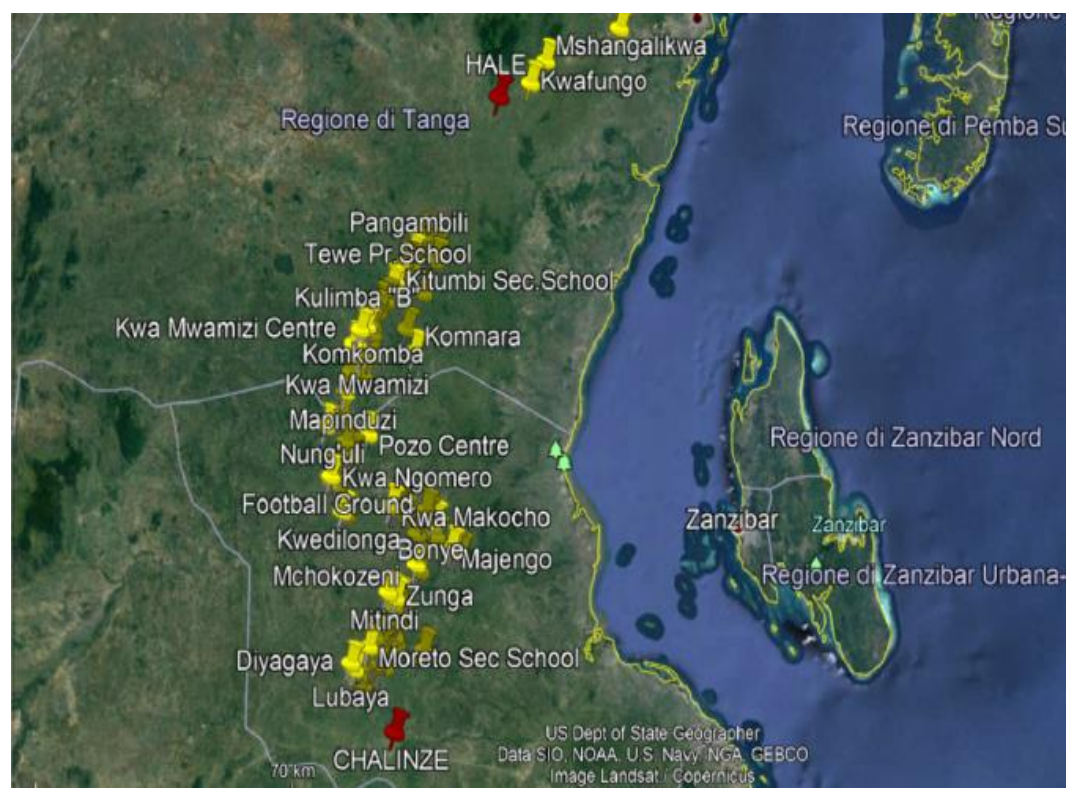

Figure 3: Villages between Chalinze and Hale without electricity. 
Mpaji village is located in Pwani region within Mbwewe ward which is $86.5 \mathrm{~km}$ from Chalinze substation and $1.8 \mathrm{~km}$ from HV TL as shown in Figure 4. The population up to December 2020 in Mpaji village was 3,052 inhabitants with 560 households. Red case shows $86.52 \mathrm{~km}$ of MV conventional method for Mpaji village electrification. Yellow case shows ISWS technology route for electrification of Mpaji village.

\section{Data type and source}

During data collection, data were obtained through observations, oral interviews, documents and records, and surveying. Additional instrument used was Miller 400D digital resistance meter with model number of 30160000-010 for measuring soil resistivity. Data collected for ISWS analysis from Chalinze-Hale-Tanga HV TL, HV/MV substations and shield wires are shown in Table 1, Table 2 and Table 3 for different parameters.

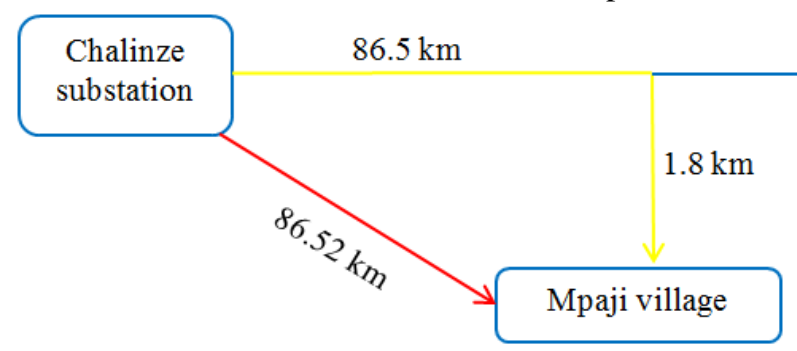

Figure 4: Physical planimetry for Mpaji village electrification.

Table 1: Chalinze-Hale-Tanga HV TL

\begin{tabular}{|c|c|c|}
\hline Parameters & Chalinze to Hale & Hale to Tanga \\
\hline Type of HV TL & Single circuit & Single circuit \\
\hline Rated voltage & $132 \mathrm{kV}$ & $132 \mathrm{kV}$ \\
\hline Type of conductor & Wolf ACSR $150 \mathrm{~mm}^{2}$ & Wolf ACSR $150 \mathrm{~mm}^{2}$ \\
\hline Length & $175 \mathrm{~km}$ & $60 \mathrm{~km}$ \\
\hline $\begin{array}{l}\text { Shield wire (material } \\
\text { type and cross section) }\end{array}$ & 2 Overhead steel wires, $50 \mathrm{~mm}^{2}$ & $\begin{array}{l}2 \text { Overhead steel wires, } \\
50 \mathrm{~mm}^{2}\end{array}$ \\
\hline $\begin{array}{l}\text { Type and presence of } \\
\text { isolators to protect TL }\end{array}$ & Air Breaker Switches (ABS) & $\begin{array}{l}\text { Air Breaker Switches } \\
\text { (ABS) }\end{array}$ \\
\hline $\begin{array}{l}\text { Type of transmission } \\
\text { towers/poles }\end{array}$ & High tensile steel structure towers & Wooden poles \\
\hline $\begin{array}{l}\text { Estimated power to be } \\
\text { transmitted }\end{array}$ & $102.88 \mathrm{MW}$ at 0.91 p.f. & $51.44 \mathrm{MW}$ at 0.91 p.f. \\
\hline $\begin{array}{l}\text { Direction of power flow } \\
\text { (mono-directional or bi- } \\
\text { directional) }\end{array}$ & Bi-Directional & Mono-Directional \\
\hline Number of towers & 532 & 389 \\
\hline
\end{tabular}


Table 2: HV/MV substation data

\begin{tabular}{llll}
\hline Parameters & Chalinze & Hale & Tanga \\
\hline $\begin{array}{l}\text { Type of } \\
\text { substations }\end{array}$ & $\begin{array}{l}\text { Public HV/MV step } \\
\text { down transformer } \\
\text { station }\end{array}$ & $\begin{array}{l}\text { Public HV/MV step } \\
\text { up and step down } \\
\text { transformer station }\end{array}$ & $\begin{array}{l}\text { Public HV/MV step } \\
\text { down transformer } \\
\text { station }\end{array}$ \\
$\begin{array}{l}\text { Rated HV/MV in } \\
\text { existence }\end{array}$ & $132 / 33 \mathrm{kV}$ & $132 / 33 \mathrm{kV}$ & $132 / 33 \mathrm{kV}$ \\
$\begin{array}{l}\text { Capacity of the } \\
\text { existence } \\
\text { transformer }\end{array}$ & $45 \mathrm{MVA}$ & $2 \times 15 \mathrm{MVA}$ & $2 \times 10 \mathrm{MVA}, 20$ \\
Soil resistivity & $7.7 \Omega \mathrm{m}$ & $60.8 \Omega \mathrm{m}$ & MVA, 55 MVA \\
\hline
\end{tabular}

Table 3: Shield wires data

\begin{tabular}{ll}
\hline Parameters & Values \\
\hline Number of shield wire & 2 \\
Shield wire resistance & $3.22 \Omega / \mathrm{km}$ \\
Shield wire reactance & $0.3755 \Omega / \mathrm{km}$ \\
Distance between shield wires & $4.00 \mathrm{~m}$ \\
Distance of HV conductors from the ground & $11.94 \mathrm{~m}$ \\
Distance of SWs from the ground & $15 \mathrm{~m}$ \\
\hline
\end{tabular}

\section{Results and Discussion Voltage drop results}

Voltage drop evaluation consists of analysis of conductor cross section of HV TL such that voltage at the last consumer is not below the acceptable limit. Technical formula has been used adding multiplication factor so as to convert the voltage drop and line loss of receiving end load to that of the distributed load. The per unit voltage drop ( $\Delta V$ ) for ISWS over certain distance is obtained using Equation (1) where $V_{L}$ is the line voltage, $r_{s w}$ is resistance of SW per $\mathrm{km}, x_{s w}$ is reactance of SW per km, $d$ is the length of the line, $P$ is the active power and $Q$ is the reactive power.

$\Delta V=\frac{d\left(r_{s w} P+x_{s w} Q\right)}{V_{L}^{2}}$

Mpaji village located between Chalinze and Hale substation, thus energizing the SWs can be made from Hale or Chalinze substation. All of the two scenarios were considered in calculating voltage drop taking into account of the loads (villages) along the HV TL. Scenario one, energizing the SWs from Chalinze substation with power flowing from Chalinze to Hale substation. Analysis was made considering the all loads between Chalinze and Hale TL which results to voltage drop of $10.89 \%$ as shown in Table 4. 
Table 4: Chalinze-Hale voltage drops

\begin{tabular}{lllll}
\hline $\begin{array}{l}\text { Village } \\
\text { wards } \\
\text { (Loads) }\end{array}$ & $\begin{array}{l}\text { Distance from } \\
\text { Chalinze }(\mathrm{km})\end{array}$ & $\begin{array}{l}\text { Active power on } \\
\text { the line }(\mathrm{kW})\end{array}$ & $\begin{array}{l}\text { Reactive power on } \\
\text { the line }(\mathrm{kVAR})\end{array}$ & Voltage $(\mathrm{kV})$ \\
\hline Chalinze & 0.0 & 782.4 & 378.9 & 33.0 \\
Msoga & 15.7 & 569.1 & 275.6 & 31.7 \\
$\begin{array}{l}\text { Lugoba } \\
\text { Msata }\end{array}$ & 22.4 & 424.6 & 205.7 & 31.3 \\
Mandera & 39.9 & 331.9 & 160.8 & 30.5 \\
Kimange & 53.8 & 281.0 & 136.1 & 30.0 \\
Mbwewe & 67.3 & 93.9 & 45.5 & 29.6 \\
Voltage drop & & - & - & - \\
\hline
\end{tabular}

Scenario two, consider energizing the SWs from Hale substation with power flowing from Hale to Chalinze substation. Analysis was made which shows the voltage drop of $80 \%$ for energizing the SWs from Hale substation as shown in Table 5.

Table 5: Hale-Chalinze voltage drop

\begin{tabular}{lllll}
\hline $\begin{array}{l}\text { Village wards } \\
\text { (Loads) }\end{array}$ & $\begin{array}{l}\text { Distance from } \\
\text { Chalinze }(\mathrm{km})\end{array}$ & $\begin{array}{l}\text { Power on the } \\
\text { line }(\mathrm{kW})\end{array}$ & $\begin{array}{l}\text { Reactive power on } \\
\text { the line }(\mathrm{kVAR})\end{array}$ & Voltage $(\mathrm{kV})$ \\
\hline Hale & 0 & 2167.07 & 1049.56 & 33 \\
Komkonga & 42.6 & 2022.08 & 979.34 & 23.49 \\
Kitumbi & 53.8 & 1755.98 & 850.46 & 20.21 \\
Mkata & 71.5 & 782.35 & 378.91 & 14.96 \\
Mbwewe & 106 & 688.50 & $333 . .45$ & 8.83 \\
Kimange & 114 & 501.39 & 242.83 & 6.70 \\
Mandera & 129 & 450.44 & 218.16 & 2.89 \\
Msata & 144 & 357.72 & 173.25 & -5.07 \\
Lugoba & 160 & 213.23 & 103.27 & -1.23 \\
Msoga & 172 & -3.06 & - & -5.83 \\
Chalinze & 175 & - & - & - \\
Voltage drop & & & & $\mathbf{8 0 \%}$ \\
\hline
\end{tabular}

Considering all of the two scenarios, Chalinze substation will be used for energizing the SWs which will result to low voltage drop.

\section{Power flow results}

Knowing the maximum power demands for the whole ISWS project taking into account all the loads located along HV TL it is very important to analyze power flow. Power losses along the line will show how power flows in energizing SWs along HV TL. Power losses along the line at each distance depend on p.f., resistance and reactance of SWs, energizing voltage of the SWs and multiplying factor (MF) as shown in Equation (2).

$$
P=\frac{V_{L}^{2} \cdot \Delta V}{M F \cdot d\left(r_{s w}+x_{s w} \tan \theta\right)}
$$

Analysis was made using Aluminum Conductor Steel reinforced (ACSR) conductors of different cross sectional area which are highly recommended for ISWS technology. Figure 5 shows how power is transferred using ACSR conductors of different cross sectional areas for three-phase system. 


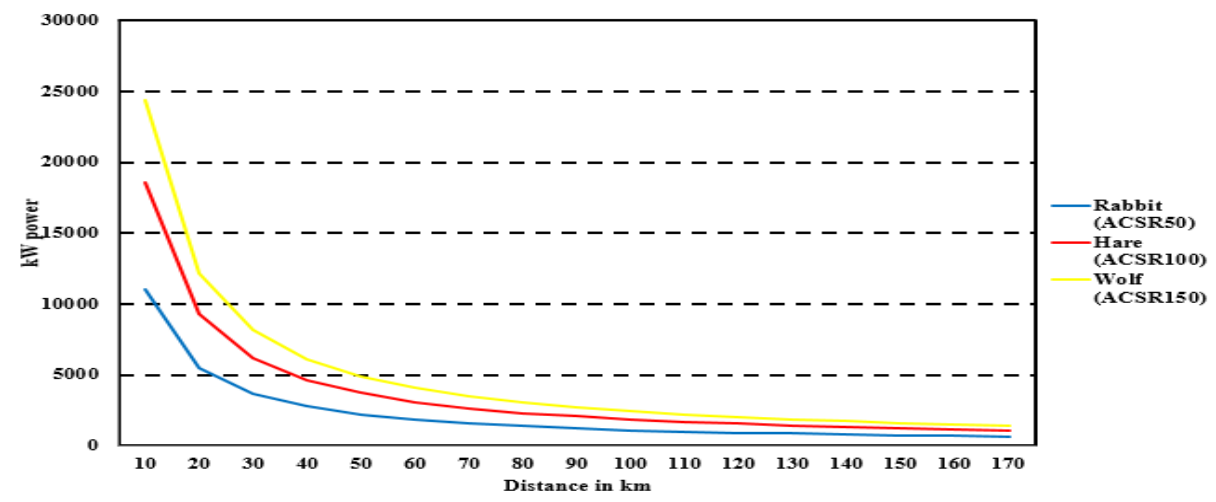

Figure 5: Power transfer capability for three-phase ACSR conductor.

Figure 5 shows that using three-phase wolf ACSR $150 \mathrm{~mm}^{2}$ conductors for SWs replacement will result into high power flow capability with minimum power loss. Twophase rabbit ACSR $50 \mathrm{~mm}^{2}$ conductors have low power transfer capability.

\section{Economic comparison results}

For MV conventional method, pole spacing according to REA standards is $80 \mathrm{~m}$ for $\mathrm{MV}$ line and $50 \mathrm{~m}$ for $\mathrm{LV}$ lines. MV conventional method route of $86.52 \mathrm{~km}$ from Chalinze substation to Mpaji village, 1,081 MV wooden poles are required. For ISWS technology MV poles will be used for the 1.8 $\mathrm{km}$ were only 22 poles will be required. The existing galvanized steel SWs are old in age and should be replaced with ACSR wires of
$150 \mathrm{~mm}^{2}$ so as to increase power flow and decrease power losses. Considering $86.5 \mathrm{~km}$ from Chalinze substation and $1.8 \mathrm{~km}$ from HV TL to Mpaji village, then for ISWS 176.6 $\mathrm{km}$ of Wolf ACSR $150 \mathrm{~mm}^{2}$ will be required. MV conventional method will require 259.56 $\mathrm{km}$ of Wolf ACSR $150 \mathrm{~mm}^{2}$.

Chalinze-Hale TL has a length of $175 \mathrm{~km}$ with 532 towers; this is equivalent to a distance of $330 \mathrm{~m}$ between towers. Mpaji village located $86.5 \mathrm{~km}$ from Chalinze substation is equivalent to 262 towers to Mpaji village. Each tower will carry 2 insulators leading to a total of 524 insulators to Mpaji village. Table 6 and Table 7 show cost analysis for supplying ISWS technology and MV conventional method for Mpaji village electrification.

Table 6: Costs for supplying Mpaji village with ISWS technology

\begin{tabular}{llll}
\hline Material & $\begin{array}{l}\text { Unit price } \\
(\mathrm{Tsh} . / \mathrm{km})\end{array}$ & Quantity & $\begin{array}{l}\text { Total price } \\
\text { (Tsh.) }\end{array}$ \\
\hline $\begin{array}{l}\text { Wooden poles }(13 \mathrm{~m} \\
\text { medium) }\end{array}$ & 492,108 & 22 & $10,826,376$ \\
$\begin{array}{l}\text { Distribution transformer } \\
(250 \mathrm{kVA}, 33 / 0.4 \mathrm{kV})\end{array}$ & $17,392,500$ & 1 & $17,392,500$ \\
$\begin{array}{l}\text { Increase of tower weight } \\
\text { ACSR conductor }\end{array}$ & 695,700 & & \\
$\begin{array}{l}\text { Insulators string and } \\
\text { assembly }\end{array}$ & $3,335,200$ & 86.5 & $60,178,050$ \\
$\begin{array}{l}\text { Capacitor banks } \\
\text { Resistor reactor compensator }\end{array}$ & $13,98,710$ & 176.6 & $588,996,320$ \\
$\begin{array}{l}\text { Labour, design, } \\
\text { transportation and }\end{array}$ & $1,500,0000$ & 524 & $109,364,040$ \\
supervision & & Lumpsum & $11,595,000$ \\
Total & & 88.3 & $13,914,000$ \\
\hline
\end{tabular}


Table 7: Costs for supplying Mpaji village with MV conventional method

\begin{tabular}{llll}
\hline Material & Unit price (Tsh./km) & Quantity & Total price (Tsh.) \\
\hline $\begin{array}{l}\text { Wooden poles (13 m } \\
\text { medium) }\end{array}$ & 492,108 & 1,082 & $532,460,856$ \\
$\begin{array}{l}\text { Distribution transformer }(250 \\
\text { kVA, 33/0.4 kV) }\end{array}$ & $17,392,500$ & 1 & $17,392,500$ \\
ACSR conductor & $3,335,200$ & 259.56 & $865,684,512$ \\
$\begin{array}{l}\text { All line insulators } \\
\text { Labour, transportation, } \\
\text { design and supervision }\end{array}$ & $2,233,046$ & 86.52 & $193,203,140$ \\
Total & $3,000,000$ & 86.52 & $259,560,000$ \\
\hline
\end{tabular}

These cost values show that the ISWS technology is $49.4 \%$ cheaper than MV conventional method for Mpaji village electrification.

\section{Profitability analysis results}

Marginal benefit-cost ratio $\left(B_{c}\right)$ will be used to determine if supplying electricity in the village with a certain distribution network would be profitable. Equation (3) shows how $\mathrm{B}_{\mathrm{c}}$ ratio can be computed.

$$
B_{c}=\frac{C_{i}}{C_{n}}
$$

Where $C_{n}$ is the number of customers connected and $\mathrm{C}_{\mathrm{i}}$ is the investment cost.

Figure 6 shows benefit-cost ratio as per Equation (3) for ISWS technology is Tsh.
1,686,993 per household and for MV conventional method is Tsh. 3,336,252 per household.

\section{Designed single line diagram}

For Mpaji rural electrification, Scheme C ISWS technology is proposed. The single line diagram is as shown in Figure 7 with the protection system. Protection system will be needed so as to protect the system in case of any failure or to isolate the system during maintenance. Calculation of the short circuit currents is a fundamental requirement to the selection of the protection equipment against the fault and their correct coordination (Bellitto 2021). The protection equipment include devices like circuit breakers, fuse and surge arrester.

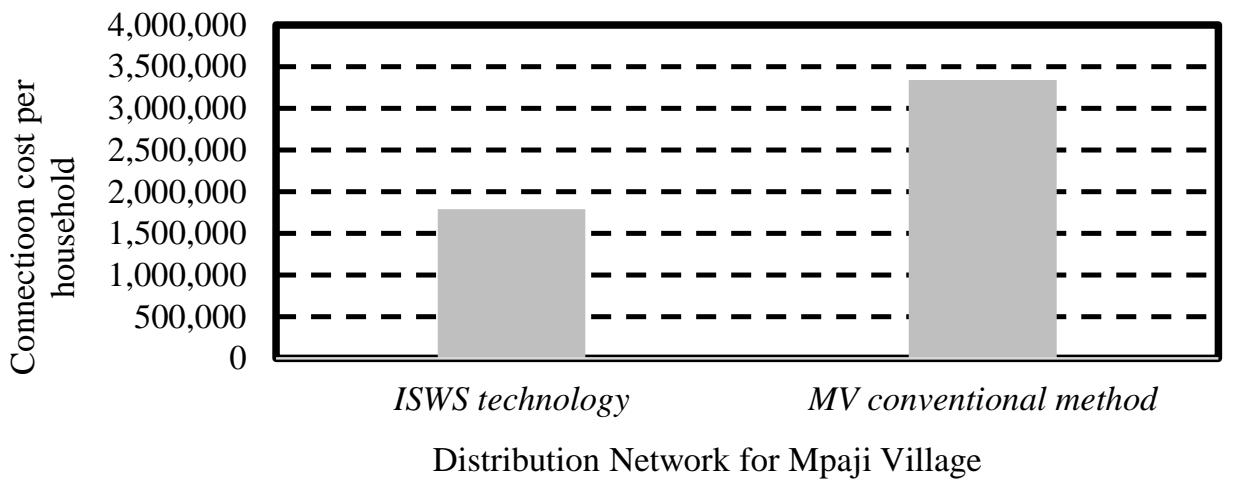

Figure 6: Benefit cost ratio analysis 


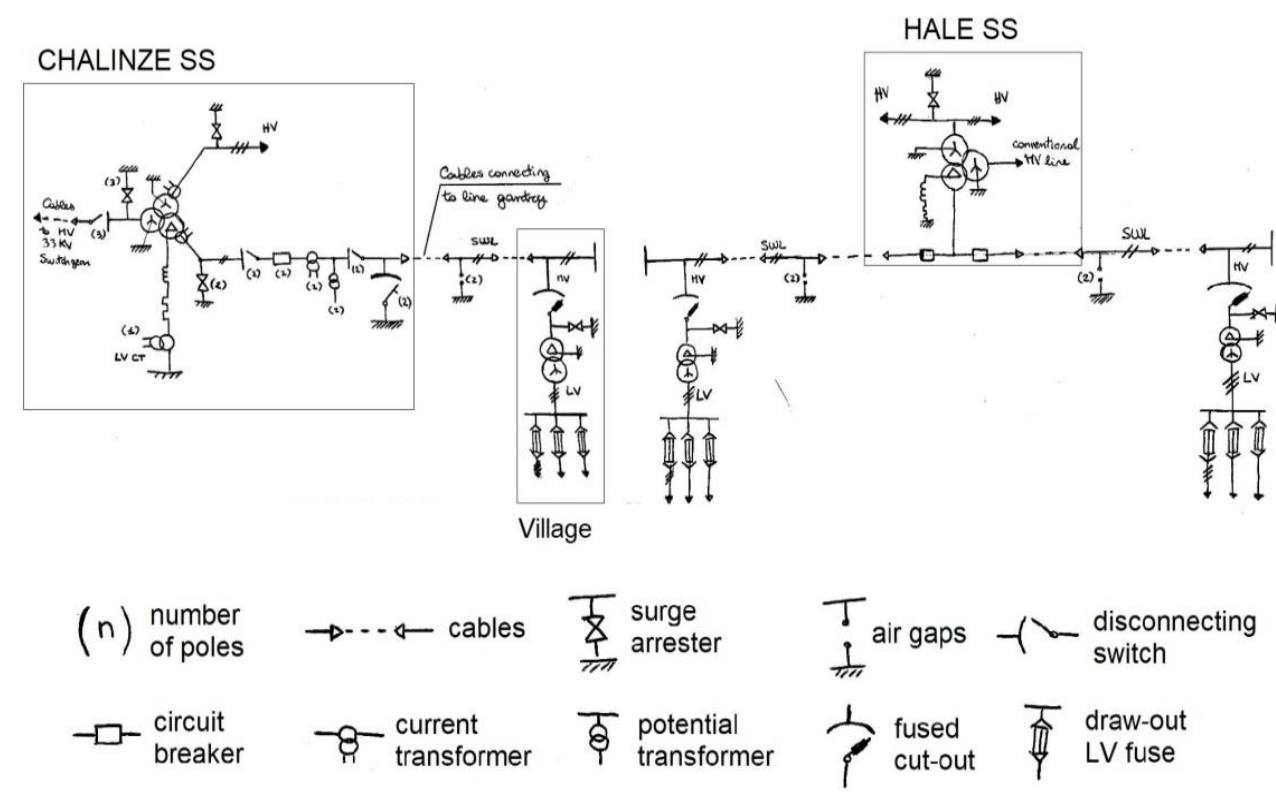

Figure 7: Single line diagram for Mpaji village electrification.

\section{Conclusion}

This paper has discussed the advantages of ISWS technology over MV conventional method for Mpaji village electrification. ISWS system showed a voltage drop of $10.8 \%$ for energizing the SWs from Chalinze substation going to Hale substation, $80 \%$ voltage drop is observed energizing the SWs from Hale substation going to Chalinze substation. ISWS technology for Mpaji village electrification is more economic than using MV conventional method (extending the grid to Mpaji village). Using ISWS technology will have investment cost of Tsh. 944,716,286.00 while for MV conventional method Tsh. 1,868,301,008.00 investment cost will be used. Using ISWS technology for Mpaji village electrification will have more saving in investment cost of about $49.4 \%$. Connection cost per household for ISWS technology electrification is Tsh. 1,686,993, while for MV conventional method is Tsh. $3,336,252$. Therefore, ISWS technology is highly recommended for Mpaji village electrification.

\section{Acknowledgement}

We are grateful to TANESCO (Tanzania Electric Supply Company), ILICEO foundation and University of Dar es Salaam (UDSM) for supporting this research.

\section{References}

Bakkabulindi G 2012 Planning models for single wire earth return power distribution networks. $\mathrm{PhD}$ dissertation, Stockholm: Royal Institute of Technology.

Bellitto G 2021 Basic design of mv power distribution system along $H V$ transmission line Chalinze-Hale-Tanga in Tanzania using Iliceto shield wire scheme (ISWS). M.Sc. Dissertation, University of Rome.

Chaves JS and Tavares MC 2018 Micro-loads electrification: Use of insulated shielding wires of a $500 \mathrm{kV}$ transmission line. Energy Sustain. Dev. 42: 109-120.

Cinieri E 1999 A new lossless circuit balancing the MV distribution systems from insulated shield wires of HV lines. IEEE Transm. Distrib. Conf. 2: 722-728.

Cinieri E, Iliceto F and Dokyi GO 1992 A new concept for the analysis of power distribution schemes at mv using the insulated shield wires of $\mathrm{HV}$ lines operation results in Ghana. 3D Africon Conference. 487-492.

EU Energy Initiative 2015 Low Cost Grid Electrification Technologies: A Handbook 
for Electrification Practitioners. Eschborn: EU Energy Initiative.

Gatta F, Iliceto F, Lauria $\mathrm{S}$ and Masato $\mathrm{P}$ 2005 Balancing methods of the 3-phase shield wire schemes. IEEE Russia Power Technol. 1-9.

Huertas JS and Tavares MC 2018 Analyzing rural electrification topologies based on induced voltage at insulated shielding wires. IEEE Trans. Power Deliv. 34(1): 53-62.

IEA 2019 Tanzania Energy Outlook. http://www.iea.org/low-cost-technologies/ (Accessed 2020 December, $1^{\text {st }}$ ).

Iliceto $F$ and Emeritus P 2016 Rural electrification with the shield wire scheme in low-income countries: design, construction and operation. Technical report 010/06, Energy Sector Management Assistance Program (ESMAP).

Iliceto F, Cinieri E, Casely-Hayford L and Dokyi G 1989 New concepts on MV distribution from insulated shield wires of HV lines: Operation results of an experimental system and applications in Ghana. IEEE Trans. Power Deliv. 4(4): 2130-2144.

Iliceto F, Gatta M and Lauria S 2002 Lightning performance of $\mathrm{HV}$ transmission lines with grounded or insulated shield wires. Int. Conf. Light. Protect. 20(2): 1-9.
Iliceto F, Gatta M, Lauria S, Debebe M and Hussen M 2005 Rural electrification in Ethiopia with the shield wire scheme. Int. Conf. Electric. Distrib. (CIRED). 45(5): 69.

Iliceto F, Gatta M, Lauria S and Dokyi O 2000 Three-phase and single-phase electrification in developing countries using the insulated shield wires of $\mathrm{HV}$ lines energized at MV. Operation experience in Ghana. Fourth Int. Conf. Power Syst. Oper. Plan. 1-8.

Iliceto F, Gatta M, Masato P and Sysoulath H 2004 Rural electrification in developing countries with the shield wire scheme: Application in Laos. International Council on Large Electric Systems (CIGRE) 1-11.

Porzi G 2021 Basic design of MV power distribution system along $H V$ transmission line Chalinze-Hale-Tanga in Tanzania using Iliceto shield wire scheme (ISWS): Integration of solar plus batteries minigrids. MSc Dissertation, University of Rome.

Shu S, Zheng Y, Xia K and Qi G 2020 Capacitive power tapping from insulated shield wire of overhead high voltage transmission lines with tuning. IEEE Trans. Power Deliv. 36(1): 191-204. 